\title{
Investigating the Effect of Levels of Proficiency on Iranian Male and Female EFL Learners' Critical Thinking and Self-efficacy
}

\author{
Shaban Barimani Varandi \\ Department of English, Science and Research Branch, Islamic Azad University, Mazandaran, Iran \\ Somayeh Mehrali \\ Department of English, Science and Research Branch, Islamic Azad University, Mazandaran, Iran
}

\begin{abstract}
This study explored relationship between Self-Efficacy and Critical thinking across different levels among Iranian EFL learners. The purpose of this study was twofold. This study attempted to expand our understanding of the relationship between psychologically rich variables like self-efficacy and critical thinking and language proficiency. Second, this research examined these psychological variables among genders. The study sample consisted of 120 students from some institutes in Tehran. Three measurements were used for data collection: firstly Nelson Test in order to define level of proficiency and homogeneity, then Self-Efficacy Scale (SES), and Critical Thinking Questionnaire (CTQ) were administered to measure their self-efficacy and critical thinking of Iranian EFL learners. In conclusion, according to statistical analysis, the findings are indicated that there is significant relationship between critical thinking and self-efficacy and levels of proficiency. Gender has significant effect on critical thinking and self-efficacy.
\end{abstract}

Index Terms — self-efficacy, critical thinking, gender, levels of proficiency

\section{INTRODUCTION}

Research on learners' beliefs has increased particularly by focusing on learners' affective and cognitive factors playing role in the language learning process. While affective factors are crucial for learning a second language (Schumann, 1998), metacognitive awareness and beliefs of learners have been had a great ipmact their learning, way of thinking, reasoning and solving the problems (Kardash \& Scholes, 1996). Additionally, belief arrangements, social cognitions and metacognition of learners consider a powerful trigger for knowledgeable performance (Schoenfeld, 1983), like learning foreign languages.

In addition, according to cognitive researches, cognitive processing is important because it determines the quality of student learning and strategies that students use in their learning like practice, explanation, organization, and critical thinking. For becoming proficient for example in learning a second language, every person requires clustering, outlining, and separating the main idea from supporting ideas. Critical thinking is how students use their former knowledge to new circumstances to solve the problems, make choices, or construct evaluations critically.

According to (Clark, 1988), he has been used 'implicit theories', 'self-constructed abstract systems as definition for beliefs (Rust, 1994, cited in Bernat \& Lloyd, 2007), and "overall assumptions that students have about themselves as learners, factors affecting learning, and also the nature of learning and teaching" (Victori \& Lockheart, 1995, p. 224). Students with positive beliefs about their own abilities would lead to effective learning strategies. On the other hand, students with negative beliefs would lead to less operative tactics that reduce their positive approach towards autonomy in learning (Victori \& Lockhart, 1995), that cause classroom anxiety (Hortwitz, et al., 1986), and lessen their cognitive in performance (Reid \& Hresko, 1981).

Bandura (1995) studied four ways for supposed self-efficacy relates to cognitive improvement. Students' selfefficacy beliefs control their own learning to become proficient in their academic activities, and become more motivated and successful person in such activities. Personal efficacy beliefs of teachers motivate and encourage learning and create learning environment to achieve academic development. Beliefs that faculties hold about their instructional efficacy to enrich their academic accomplishment. In general, we can regard self-efficacy as a motivational cause in the improvement of critical thinking ability.

By considering motivations and interests of learners as vital features in their critical thinking (Myers, 1992, cited in Dehghani et al, 2011), students' positive beliefs in their abilities comes to motivation that faster critical thinking and negative or non-motivation ones would be a difficulty to critical thinking. As a result, self-efficacy beliefs can successfully predict critical thinking abilities (Sang, Valcke, Braak \& Tondeur, 2010). Bandura and Lock (2003) believe that self-efficacy give rise to motivation and expands performance and critical thinking skills.

Self-efficacy beliefs originated from Bandura's (1977) social learning theory that the name of theory was modified to social cognitive theory in 1986. One of the most important theories that Bandura applied in his theory was self-efficacy. 
Bandura (1995) made a difference in how people feel, think, behave, and motivate themselves regarding self-efficacy presented in his theory. Concerning feeling, a low sense of self-efficacy causes stress, anxiety, depression, and helplessness.

Regarding thinking, better sense of efficacy facilitates cognitive processes and consequently performance, including academic accomplishments and decision making. And regarding behaving, self-efficacy can affect choice of activities that people choose. Self-efficacy levels would measure peoples' degree of motivation. People that have higher selfefficacy choose more demanding tasks to challenge and try to achieve it. "People's level of motivation would be determined by self-efficacy beliefs, as reflected in how much effort they will put forth and how long they will persevere when they face obstacles" (Bandura, 1982, p. 11). To sum up, the higher the sense of efficacy, the greater the effort, persistence and resiliency will be (Parajes, 1996, p. 544).

We could look at critical thinking form two points of view; philosophical view and psychological one. From philosophical point of view, origins of critical thinking can be traced back to Socrates and the Socratic Method. It is a philosophy that helps people to repair vague meanings, contradictory beliefs, inadequate evidence and empty expression (Paul, Elder \& Bartell, 1997). In this method, it is important to search for evidence, examine reasoning and suppositions, analyze conceptions, and trace out inferences. The philosophy proposed by Socrates was persuaded by Plato and the Greek skeptics, they highlighted that things are often unlike what they appear to be and the skilled mind is just equipped to see what actually they are (Paul, Elder \& Bartell, 1997, cited in Duron, Limbach \& Waugh, 2006).

From psychological point of view, critical thinking is the ability to examine and assess information. Critical thinkers raise essential questions, formulate those questions, collect relevant information and then assess them, think openmindedly, and communicate efficiently. In contrast, passive thinkers undergo a restricted view; their responses are yes or no and think their perspectives are the only reasonable and relevant viewpoint. Critical thinking is an important and necessary to deal with mental questions, and it can be used to assess people, policies, and institutions that avoid facing social problems (Hatcher and Spencer, 2005).

Halpern (1996) defined critical thinking as "thinking that is purposeful, reasoned, and goal directed. It is the way of thinking that is involved in solving problems, formulating inferences, calculating likelihoods, and making decisions" (p. 5) and he like most cognitive-based theorists preferred to use "thinking skills" specifically not as a broad term for the movement (Lewis \& Smith, 1993; Sternberg, 1987). As a result, critical thinking and self-efficacy are two major student characteristics need to be investigated in more details in educational settings. In this study, the researcher plans to have a precise look and examine these two cognitive situations in three level of proficiency along with considering gender differences. This may affect enrolment for college courses, career choices, and even in their social settings.

\section{Statement of the Problem}

In most school classes and institutes in Iran, learners feel bored and tired because there are some missing points from psychological point of view that make them biased towards their learning and classrooms. Most of the time, these missing points like critical thinking and self-efficacy have a great effect on language teaching and learning in classroom and ignoring them would lead to ineffective teaching strategies and wasting time. Taking the importance of language teaching and learning in today's world into consideration, and undeniable role of psychological matters, this study aimed to determine the most important factors including critical thinking, self-efficacy across different levels of proficiency among different genders. As a result, understanding students' needs and knowing psychological attitudes have always been one of the obsessing issues among language teaching experts.

\section{RESEARCH QUESTIONS}

Based on the purpose of the study, the researcher raised the following questions:

1. Is there any significant difference between critical thinking and self-efficacy of Iranian EFL learners at lower intermediate, intermediate and upper intermediate levels of proficiency?

2. Does gender have any significant effect on Iranian EFL learners' critical thinking ability?

3. Does gender have any significant effect on Iranian EFL learners' self-efficacy beliefs?

\section{RESEARCH HYPOTHESES}

On the basis of the aforementioned research questions the following hypothesis are stated:

1. There is no significant difference between critical thinking and self-efficacy among EFL learners' lower intermediate, intermediate and upper intermediate levels.

2. There is no significant difference between genders of EFL learners in terms of critical thinking ability.

3. There is no significant difference between genders of EFL learners and their self-efficacy beliefs.

\section{METHOD}

\section{A. Participants}


The participants of this study were 120 students from some institutes in Tehran. The participants were mostly selected from adults at three different levels of proficiency and divided into three groups of lower intermediate, intermediate and upper intermediate. The reason why the participants should be from adults is that thinking and answering to psychological questionnaires needs some degree of maturity so the researcher selected them from adult learners. To secure the reliable homogeneity of the selected participants, the researcher used Nelson quick check test. Among 120 subjects who took the test and based on the obtained mean and standard deviation, only 96 participants were selected and then the participants were divided into three groups accordingly.

\section{B. Materials}

In the current study, one standard test as pre-test and two questionnaires were used to collect required data. The pretest, Nelson's Quick Check Test was administered to determine the participants' level of proficiency. One of the questionnaires was on self-efficacy (The General Self-Efficacy Scale written by Ralf Schwarzer \& Matthias Jerusalem, 1979) and another was a critical thinking questionnaire adopted from Ballarat University.

\section{Nelson Test}

In order to fulfill the aim of this research, test of Nelson by Fowler and Coe (1978) was selected and the researcher gave it to all participants to determine level of proficiency and secure homogeneity. This test includes 100 items arranged from easy to difficult including grammar and vocabulary. The maximum time required for this test is 60 minutes. This test was chosen because it is one of the most reliable tests used to determine the level of proficiency.

General Self-Efficacy Scale (GSE)

The General Self-Efficacy Scale (GSE) by Ralf Schwarzer and Matthias Jerusalem (1979) was selected for assessing participants' self-efficacy due to the fact that it is the most popular and reliable questionnaire in this area. The German version developed in 1979 and revised and adapted to 26 other languages later. This questionnaire was made to evaluate an overall sense of perceived self-efficacy to see how people deal with their daily difficulties and adaptation after experiencing stressful life events. The scale is designed for the general adult population includes totally 10 items and is a series of statements about participants' personal attitudes and traits. The time allocated is 4 minutes on average and each statement has 4 options to answer. Regarding the reliability of this scale, it should be notified that samples were chosen from 23 nations, Cronbach's alphas ranged from .76 to .90, with the majority in the high $.80 \mathrm{~s}$.

Critical Thinking Questionnaire

The Critical Thinking questionnaire was included 20 items that measures students' skills at analyzing, evaluating, and extending arguments. This questionnaire was adopted from The University of Ballarat (UB) website that is an Australia's multi-sector university. There were five answers for each item (Likert scale) from strongly agree to strongly disagree. It is designed to permit test-takers to demonstrate how much the participants are critical thinker in settings where solving problems and making decisions are important. Since there was no access to the information of reliability of the questionnaire, the test was piloted to get sure about the reliability. Consequently, the questionnaire was given to volunteer participants other than those involved in this study. Cronbach's Alpha Reliability Coefficient for Likert-Type Scales was used and equalled to 0.70 that is acceptable and could be considered a standard test.

\section{Procedures}

A survey study was conducted to collect quantitative data from 96 selected students as participants. Data collection was in the form of paper-and-pencil testing administered in two sessions. Firstly, the pre-test have been administered to determine the participants' level of proficiency. For this purpose and to save time Nelson's quick check test was given to all participants. In order to secure the homogeneity, the mean and standard deviation of the obtained scores were calculated. After homogenizing and defining the participants, the researcher gave questionnaires to them. Since some words would be difficult to understand specifically for beginner and in some cases for intermediate participants, the researcher translated questionnaires in order to avoid any misunderstanding. The participants were also asked to answer the questions honestly and carefully.

The pre-test and questionnaires were done in two separate sessions. However, because the New Year holidays were close to the time of data collection, the pretest was given before the holidays and the questionnaires were given after the holidays.

\section{DATA ANALYSIS}

Nelson was administered to 120 EFL learners. The descriptive analysis of the data obtained through Nelson test is presented in table 1 .

TABLE 1.

\begin{tabular}{|c|c|c|c|c|c|c|c|c|c|}
\hline & $\mathrm{N}$ & Minimum & Maximum & Mean & Std. Deviation & Skewness & & Kurtosis & \\
\hline & Statistic & Statistic & Statistic & Statistic & Statistic & Statistic & Std. Error & Statistic & Std. Error \\
\hline Proficiency Test & 120 & 23 & 78 & 41.13 & 13.728 & .943 & .221 & .264 & .438 \\
\hline
\end{tabular}


In order to guarantee the homogeneity of the participants, the students whose scores did not fall within a range of one standard deviation above and below the mean were eliminated from the main study. Regarding this study, 40 students were excluded. The descriptive statistics of the homogeneous participants are provided in Table 2 .

TABLE 2.

DESCRIPTIVE STATISTICS OF THE HOMOGENOUS PARTICIPANTS

\begin{tabular}{|c|c|c|c|c|c|c|c|c|c|}
\hline & $\mathrm{N}$ & Minimum & Maximum & Mean & Std. Deviation & Skewness & & Kurtosis & \\
\hline & Statistic & Statistic & Statistic & Statistic & Statistic & Statistic & Std. Error & Statistic & $\begin{array}{l}\text { Std. } \\
\text { Error }\end{array}$ \\
\hline $\begin{array}{l}\text { Proficiency } \\
\text { Test }\end{array}$ & 80 & 28 & 60 & 40.21 & 9.000 & .502 & .254 & -.866 & .503 \\
\hline
\end{tabular}

Regarding the purpose of study that is to investigate different levels of language proficiency of learners, the participants of the study were then divided into three levels of language proficiency. To do this, one standard deviation below the mean was identified as lower level, one standard deviation above the mean as intermediate level and two standard deviations as upper level learners. The learners who were not scored within these ranges were excluded from the study. The descriptive statistics of three groups of the language proficiency is provided in Table 3 . The number of the participants in lower, intermediate and upper level groups is 37, 28 and 15 respectively.

TABLE 3.

DESCRIPTIVE STATISTICS OF THREE LEVELS OF LANGUAGE PROFICIENCY

\begin{tabular}{llllll} 
& \multicolumn{5}{c}{ DESCRIPTIVE STATISTICS OF THREE LEVELS OF LANGUAGE PROFICIENCY } \\
\hline & $\mathrm{N}$ & Minimum & Maximum & Mean & Std. Deviation \\
Lower & 37 & 31 & 39 & 34.02 & 4.065 \\
Intermediate & 28 & 40 & 49 & 50.52 & 4.999 \\
Upper & 15 & 50 & 59 & 65.59 & 4.345 \\
Total & 80 & & & & \\
\hline
\end{tabular}

In order to see whether there is any significant difference between critical thinking and self-efficacy among EFL learners of lower intermediate, intermediate and upper intermediate, the following steps were taken. The descriptive statistics of critical thinking ability and self-efficacy of each level is provided in Table 4. It provides useful information on mean and standard deviation of self-efficacy and critical thinking ability among three groups of the study.

TABLE 4.

DESCRIPTIVE STATISTICS OF THREE LEVELS ON SELF-EFFICACY AND CRITICAL THINKING

\begin{tabular}{lllll}
\hline \multirow{3}{*}{ Self-Efficacy } & Groups & Mean & Std. Deviation & N \\
& Lower & 26.80 & 1.494 & 37 \\
& Intermediate & 31.13 & 2.052 & 28 \\
& Upper & 36.35 & 1.618 & 15 \\
Critical Thinking & Total & 27.15 & 5.995 & 80 \\
& Lower & 36.63 & 7.598 & 37 \\
& Intermediate & 66.04 & 10.585 & 28 \\
& Upper & 75.88 & 7.296 & 15 \\
& Total & 50.63 & 18.857 & 80 \\
\hline
\end{tabular}

A one-way Multiple Analysis of Variances (MANOVA) was performed in order to see whether there are significant differences between different levels of language proficiency and their self-efficacy and critical thinking ability. The results are provided in Tables 5 and 6.

\begin{tabular}{|c|c|c|c|c|c|c|c|}
\hline \multicolumn{8}{|c|}{$\begin{array}{l}\text { TABLES } 5 . \\
\text { MANOVA }\end{array}$} \\
\hline \multicolumn{2}{|l|}{ Effect } & Value & $\mathrm{F}$ & Hypothesis df & Error df & Sig. & $\begin{array}{l}\text { Partial Eta } \\
\text { Squared }\end{array}$ \\
\hline \multirow[t]{4}{*}{ Intercept } & Pillai's Trace & .993 & $6.540 \mathrm{E} 3 \mathrm{a}$ & 2.000 & 92.000 & .000 & .993 \\
\hline & Wilks' Lambda & .007 & $6.540 \mathrm{E} 3 \mathrm{a}$ & 2.000 & 92.000 & .000 & .993 \\
\hline & Hotelling's Trace & 142.183 & $6.540 \mathrm{E} 3 \mathrm{a}$ & 2.000 & 92.000 & .000 & .993 \\
\hline & Roy's Largest Root & 142.183 & $6.540 \mathrm{E} 3 \mathrm{a}$ & 2.000 & 92.000 & .000 & .993 \\
\hline \multirow[t]{4}{*}{ Levels } & Pillai's Trace & .932 & 40.559 & 4.000 & 186.000 & .000 & .466 \\
\hline & Wilks' Lambda & .111 & $92.263 \mathrm{a}$ & 4.000 & 184.000 & .000 & .667 \\
\hline & Hotelling's Trace & 7.651 & 174.058 & 4.000 & 182.000 & .000 & .793 \\
\hline & Roy's Largest Root & 7.600 & $3.534 \mathrm{E} 2 \mathrm{~b}$ & 2.000 & 93.000 & .000 & .884 \\
\hline $\begin{array}{l}\text { a. Exact st } \\
\text { b. The sta } \\
\text { c. Design: }\end{array}$ & $\begin{array}{l}\text { tistic } \\
\text { stic is an upper boun } \\
\text { ntercept + Levels }\end{array}$ & yield & tom & gnificance & & & \\
\hline
\end{tabular}

The results are provided in tables 5. and 6. showed that $(p=0)$. So, pvalue is lower than the assumed level of significance (i.e., 0.05) and therefore there are significant differences among different levels of proficiency.

Using Wilks' Lambda test, it was found that there are significant differences (Wilk's $=.11, F_{4,184}=92.26, p<.05$ ), among different levels of language proficiency in their critical thinking and self-efficacy. Multivariate $\left(\mathrm{y}^{2}=.66\right)$ 
The present study also suggested the importance of improving the learners' English language proficiency. As discovered by the results, proficiency in English is positively related to critical thinking ability and self-efficacy, it means that if the learners are proficient in English, their critical thinking ability and self-efficacy will also be intensified. Of course, it should be noticed that these competencies can be developed independently of each other; that is, there are learners who are proficient in English and yet poor in critical thinking and self- efficacy.

Although in this study the difference between three levels of proficiency in critical thinking and self-efficacy is significant, it should be considered that language is not exclusively responsible for determining learners' thought but it could be helpful to shape their thought.

In this part, the second research question is dealing with the relationship between critical thinking, self-efficacy, and gender. So, this research question aimed to see whether there is significant difference between female and male learners in critical thinking ability and self-efficacy beliefs. According to the result of paired-sample t-tests, there is significant difference between female and male learners in critical thinking ability and self-efficacy beliefs.

These results are in contrast to what Dehghani et al. (2011) found, in that there was a significant difference between learners' self-efficacy by gender. The findings are in line with those of critical thinking and they found that there is no significant difference between learners' critical thinking by gender. It also supports those of Curtis et al. (2008) in that there is no significant difference between learners' critical thinking by gender. However, findings of this study are the same as what Murris (2002, cited in Dehghani et al., 2011) found in his study. He found that there is no significant difference between students' self-efficacy by gender.

\section{IMPLICATIONS}

From theoretical point of view, successful language performance requires higher ability in critical thinking and better beliefs in self-efficacy. This study presented critical thinking and self-efficacy as potential factors for language learning achievement.

From pedagogical point of view, EFL teachers by considering cognitive and affective factors like critical thinking and self-efficacy in their language teaching methodology and employing proper strategies and tasks could help learners to overcome difficulties in language learning process. For example, they could employ tasks that provide opportunities for learners to increase their critical thinking ability.

English institutes, schools, and colleges could benefit from the findings of the present study and they could put such beneficial factors into practice and design their curriculum and material on the basis of the learners' affective and cognitive factors. Additionally, learners are more willing to enroll in institutes and colleges that pay attention to their feelings and at the same time help them to increase their abilities in learning process.

\section{SugGeStions FOR FurTher RESEARCH}

According to the findings of this study, level of proficiency in English has a significant relationship with critical thinking ability and self-efficacy beliefs, but as I mentioned earlier, language is not the only responsible item for determining learners' thought and it could just help to shape their thought. There are other factors affects these two variables like entering social life and being educated. As people enter social life, they gain more experience and success so they improve their self-efficacy on the basis of those successes and the more successful experience they gain the more self-efficient they become.

It is also true when it comes to education, when people continue their education to higher level; they get more success that leads to being more self-efficient and better critical thinker. As their level of education develops, they start using skills or approaches of cognition that surge the possibility of a required outcome. They start thinking that is goal directed and it is better to state more directed thinking.

As a result of the mentioned issues, further researches is recommended in investigating the above factors in the relation with critical thinking and self-efficacy that the researcher had to skip for the sake of time. Also, the researchers could consider subcategories of critical thinking and self-efficacy is highly recommended for further studies.

A need is also felt to investigate critical thinking and self-efficacy of the teachers that play key role in the field of English language teaching in language classes and learn how to improve them that affect their teaching drastically. A study in this case would be helpful for both teachers and students. If the teachers could improve their critical thinking and self-efficacy, they would be able to teach more effectively and at the same time they could help students to improve their psychological issues better.

\section{REFERENCES}

[1] Bandura, A. (1982). Self-efficacy mechanism in human agency. American Psychologist, 37(2), 122-147

[2] Bandura, A. (1995). Self-Efficacy in Changing Societies (3th ed.) (pp.1-45). Cambridge University Press, United Kingdom.

[3] Bandura, A., \& Lock, E., A. (2003). Negative Self-efficacy and goal effects revisited. Journal of Applied Psychology, 88, 87-99. 
[4] Clark, C. (1988). Asking the right questions about teacher preparation: Contributions of research on teaching thinking. Educational Researcher, 17, 5-12.

[5] Dehghani, M., Sani, H. S., Pakmehr, H., \& Malekzadeh, A. (2011), Relationship between Students' Critical Thinking and Self-efficacy Beliefs, Procedia Social and Behavioral Sciences 15 (2011) 2952-2955. ELSEVIER publication. Retrieved August 10, 2013 from www.sciencedirect.com.

[6] Duron, R., Limbach, B., \& Waugh, W. (2006). Critical Thinking Framework for Any Discipline. International Journal of Teaching and Learning in Higher Education, 17( 2), 160-166.

[7] Halpern, D. F. (1992). Sex Differences in Cognitive Abilities (2nd Ed.). Hillsdale, NJ: Lawrence Erlbaum Associates, Inc.

[8] Hatcher, D. L., \& Spencer, L. A. (2005). Reasoning and Writing: From Critical Thinking to Composition. 3rd. ed. Boston: American Press.

[9] Horwitz, E. K., Horwitz, M. B., \& Cope, J. (1986). Foreign language classroom anxiety. Blackwell Publishing and National Federation of Modern Language Teachers Associations, 125-132.

[10] Lewis, A., \& Smith, D. (1993). Defining higher order thinking. Theory into Practice, 32 (3), 131-137.

[11] Newman, J.H. (1996). The Idea of a University, ed. Frank M. Turner, Series: Rethinking the Western Tradition. London: Yale University Press.

[12] Kardash, D. A., \& Scholes, R. J. (1996). Effects of pre-existing beliefs, epistemological beliefs, and need for cognition on interpretation of controversial issues. Journal of Educational Psychology, 88(2), 260-271.

[13] Pajares, F. \& Johnson, M. J. (1996). Self-efficacy beliefs in writing of high school students: A path analysis. Psychology in the Schools, 33, 163-175.

[14] Rodgers, C. (2002). Defining reflection: another look at John Dewey and Reflective Thinking, Teachers Colleges Record; volume 104, June 2002, 842-866.

[15] Rosyati A. R., \& Rosna A. H. (2008). The Relationship between Critical Thinking and Language Proficiency of Malaysian Undergraduates. Originally published in the Proceedings of the EDU-COM 2008 International Conference. Edith Cowan University, Perth Western Australia, 19-21 November 2008.

[16] Reid, D. K., \& Hresko, W. P. (1981). A cognitive approach to learning disabilities. New York: McGrawHill.

[17] Sang, G., Valcke, M., Braak, J., \& Tondeur, J. (2010). Student teachers' thinking processes and ICT integration: Predictors of prospective teaching behaviors with educational technology. Computers and Education. 54(1). P.103-112.

[18] Schoenfeld, A. H. (1983). Beyond the purely cognitive: Belief systems, social cognitions, and metacognitions as driving forces in intellectual performance. Cognitive Science, 7, 329-363.

[19] Schumann, J. H. (1998). The Neurobiology of Affect in Language. MA: Blackwell Publishers Ltd.

[20] Sternberg, R. J. (1987). Teaching intelligence: The application of cognitive psychology to the improvement of intellectual skills. In J. B. Baron \& R. J. Sternberg (Eds.), Teaching thinking skills: Theory and practice (pp. 182-218). New York: W. H. Freeman.

[21] Victori, M., \& Lockhart. W. (1995). Enhancing metacognition in self-directed language learning. System, 23(2), $223-234$. Retrieved from www.sciencedirect.com (accessed 27/8/2013).

Shaban Barimani Varandi was born in Iran in 1956. He received a Ph.D. in TEFL (Teaching English as a Foreign Language) from Mysore University in 2009 in India, an M.A. in TEFL from Islamic Azad University in Iran, in 2001, and a B.A. in TEFL from UTE (University for Teacher Education) in Tehran, Iran in 1989.

As for his professional background, he is the chairman of the EFL department at Islamic Azad University, Sari Branch since 2009 up to now and a member of the faculty member of English Language and Linguistics in Islamic Azad University, Sari Branch since 2002. Now, as chairman in TEFL and Linguistics and as an associate professor, he runs courses in Linguistics, Research, Testing, and methodology in Sari and Mazandaran Science \& Research branches of Islamic Azad University at the levels of BA and MA.

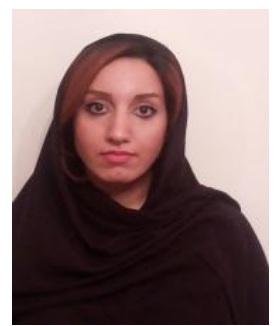

Somayeh Mehrali was born in 1982. She is currently an educated student in MA from Islamic Azad University, Science and Research branch, Mazandaran, Iran. She got her BA in English Translation from Islamic Azad University. She has been teaching English for about 3 years at different institute. She has translated a couple of articles, and presented a paper inside the country. Her areas of interest include Psychological issues of EFL and Language Acquisition and Assessment. 